\title{
Lemon Extract as an Alternative Etching Materials on Composite Resin Restoration Against Shear Strength
}

\author{
Nadia Putri Syawalia $^{1}$, Endanus Harijanto ${ }^{2}$, R. Moh. Yogiartono ${ }^{2}$ \\ ${ }^{1}$ Undergraduate Student of Dental Medicine, Department of Dental Material Science and Technology, Faculty \\ of Dental Medicine, Universitas Airlangga, ${ }^{2}$ Staff of Biomaterial Department, Faculty of Dental Medicine, \\ Universitas Airlangga
}

\begin{abstract}
Background: Composite restoration is an adhesive (mechanical interlocking) restoration, which is from resin tags on micro porosity on the etched surface of the enamel. Etching is to clean the smear layer and forming porous on the enamel surface as to provide mechanical retention in the restoration. The acidic etching material that is often used is phosphoric acid with a concentration of $37 \%$, but $37 \%$ phosphoric acid can cause inflammatory cell infiltration. Lemon contains citric acid, a weak acid that has the potential to be an alternative to acid etching.
\end{abstract}

Purpose: To find out the effect of lemon extract as an alternative etching material on the shear strength of composite resin.

Method: 14 samples of bovine teeth incisors were divided into two groups. Each group consisted of 7 samples, then cavity preparation. Group 1 with $37 \%$ phosphoric acid etching, group 2 with lemon extract. The samples were bonded, filled with composite resin and carried out shear strength tests.

Results: There was no significant difference in shear strength from the composite resin group with $37 \%$ phosphoric acid etching and composite resin group with lemon extract.

Conclusion: Lemon extract can be used as an alternative material for acid etching in composite resin.

Keywords: Shear strength, lemon extract, 37\% phosphoric acid etching and composite resin.

\section{Introduction}

Recently, the field of dental medicine, composite resins have begun to be widely used as anterior and posterior restorative materials, due to the demand of patients who want tooth-colored restoration ${ }^{1}$. Composite resins are increasingly popular because they have good aesthetics and good mechanical strength, among others are not easily separated from the tooth surface, not easily

\footnotetext{
Corresponding Author:

Endanus Harijanto

J1. Prof. Dr. Moestopo No. 47

Phone Numbers: (+6231) 5030255, 5020256

Facsimile Numbers: (+6231) 5020256

e-mail: endanus-h@ffkg.unair.ac.id
}

cracked and broken, has a high visual opacity and low polymerization shrinkage. ${ }^{2}$

Composite resins are restorations whose basic principle of bonding with teeth is micromechanical (mechanical-interlocking) ${ }^{2}$, i.e. from resin tags on micro porosity on the enamel surface that has been etched ${ }^{3}$.Etching is performed to clean the smear layer and produce small pores on the enamel surface, so can provide mechanical retention in restoration ${ }^{4}$.

Acid etching material that is often used is phosphoric acid with concentrations ranging from $30-40 \%$, but the most widely used concentration is $37 \% 5$. Phosphoric acid is a strong acid, 6 is able to release more hydrogen ions than weak acids, because it is able to completely mineralize ${ }^{6}$. 
The strong acid can cause hydroxyapatite to dissolve so that the demineralization process occurs on the enamel surface ${ }^{7}$. When the composite resin is applied to the enamel surface that has been etched ${ }^{8}$, the resin will flow on the irregular surface and form a resin tag 9 , resulting in mechanical interlocking of the resin on the resin enamel ${ }^{3}$.

The use of phosphoric acid can be dangerous to the dental pulp ${ }^{10}$. Phosphoric acid can cause excessive demineralization so that it will increase the permeability of the dentin. Penetration of etching material will be more through the dentinal tubules into the pulp. The etching material of phosphoric acid with low $\mathrm{pH}$ causes the environment outside the cell to be hypertonic, so that the fluid inside the cytoplasm will be pulled out and the cell will contract. This can trigger permanent damage to odontoblast cells and cause an inflammatory reaction ${ }^{11}$. The effects of using potentially harmful chemicals can be minimized by using alternative medicinal plants.

To overcome the shortcomings of etching that can irritate the dental pulp, natural materials that can replace etching, one of them with lemons. Lemon contains organic acids which are citric acid. Citric acid is a chelating solution that is able to remove the smear layer on the cavity so as to increase contact between the cavity surface and the restoration material ${ }^{12}$.

The shear strength test for tooth restoration is one way to measure the adhesion strength of the material ${ }^{13}$ to the restored tooth structure besides the tensile strength test ${ }^{14,15}$. In this research the magnitude of force acceptable for composite resin restorations was measured when the restorations were detached from the tooth surface. Shear strength can indicate how the adhesion occurs in vitro ${ }^{16}$.
The value obtained from the shear strength test is not absolute, but the value of the test results can be used to help compare an adhesive material. This research was conducted to find out more about the effect of lemon extract as an alternative etching material to the composite resin shear strength.

\section{Materials and Method}

The ingredients used were bovine teeth, 37\% phosphoric acid, lemon extract, sterile aquadest, 96\% ethanol, $0.9 \% \mathrm{PZ} / \mathrm{NaCl}$ solution, cotton pellet, composite resin bonding and composite resin.

The sample making of bovine teeth is as follows, each bovine teeth separated by the crown and roots, then planted on top of acrylic with the labial surface facing up. The sample was prepared in the labial section of a cylinder with a diameter of $4 \mathrm{~mm}$ and into $2 \mathrm{~mm}$ with contra angle low speed. Tooth cavity is checked using a sonde, to see the surface is smooth and then rinsed using distilled water and dried.

Making liquid lemon extract is as follows, as much as 1000 grams of lemon is prepared, washed clean, cut into small pieces and mashed with $96 \%$ ethanol as much as 2 liters using a blender. Lemon that has been smooth is transferred into a 2 liter volume jar for soaking (maceration) for 3 days. After 3 days soaking, then filtered with filter cloth separated the pulp with the filtrate. The ethanol filtrate was evaporated with a rotary evaporator with a temperature of $60^{\circ}$ and ethanol pressure of 175 mbar until the solvent completely evaporated. The liquid yield of lemon extract was 165 $\mathrm{ml}$, then the $\mathrm{pH}$ of the lemon extract is measured using litmus paper, around 2.5 .

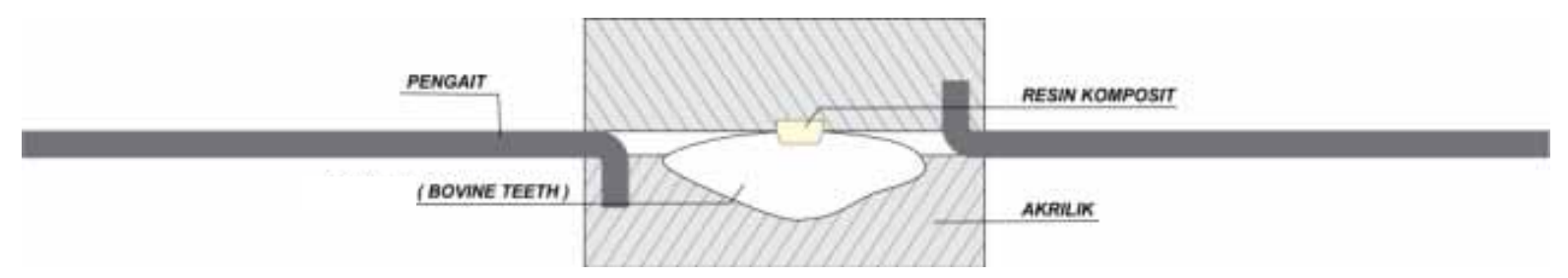

Figure 1. Sample tested

The next treatment procedure, bovine teeth were etched for 20 seconds, the samples were divided into 2 groups, namely group I: bovine teeth etched with $37 \%$ phosphoric acid, group II: bovine teeth) which was etched with liquid lemon extract. The etching material was rinsed with distilled water $\pm 1 \mathrm{cc}$ until clean, then dry using blow dry for 10 seconds. Resin bonding was dropped on a microbrush as much as 1 drop $(0.01 \mathrm{ml})$ and 
applied to the surface of the cavity, irradiated with light curing for 10 seconds (visible light with a wavelength of 400-800nm). Composite resin was applied using a plastic filling instrument on the cavity layer by layer as many as 3 layers to meet the cavity, each layer was condensed and shined by using light cure. Samples were stored in a room temperature tool box for 24 hours. Shear strength testing uses a Universal Testing Machine (Autograph).

\section{Result}

Average and standard deviation of composite resin with phosphate and lemon extract can be seen on Table 1 .

\section{Table 1. Average and stand deviation of composite resin with phosphate and lemon extract}

\begin{tabular}{|l|c|c|c|}
\hline Group & n & Average & Standard Deviation \\
\hline Group I & 7 & 12.5054 & 0.59058 \\
\hline Group II & 7 & 12.9943 & 0.73885 \\
\hline
\end{tabular}

\section{Information:}

a. Group I: Bovine teeth etched with $37 \%$ phosphoric acid

b. Group II: Bovine teeth etched with liquid lemon extract

Normality test with the Kolmogorov-Smirnov Z test in both groups obtained $p$ value for composite resin group with phosphoric acid etching $p$ value $=0.200$ (p> 0.05 ) and for composite resin group with lemon extract obtained $p$ value $=0.200(p>0,05)$. This shows that the data from the two groups are normally distributed. After knowing the data the two groups were normally distributed then Independent T-Test was conducted.

Levene test results obtained a significant level of 0.629 which indicates that the variance of homogeneity of data is normal. The statistical test was continued with the Independent T-Test by using the results in the normal variant sequence. The results of the Independent T-Test in the sample group A and sample B obtained a significant level of $p=0.197(p>0.05)$. This shows that there is no significant difference between the shear strength of composite resins with acid etching and composite resins with lemon extract.

\section{Discussion}

This research uses incisive cow's lower teeth. Lower mandibular incisors are used because they are easier to obtain and are easily standardized. The chemical and micromorphological composition between bovine teeth and human teeth also has similarities. The results showed that the amount of inorganic pyrophosphate in enamel and dentin bovine teeth and human teeth was almost the same ${ }^{17}$. The research was conducted to determine the difference in shear strength of composite resins using 37\% phosphoric acid etching with composite resins using lemon extract. The magnitude of the shear strength (MPa) is assessed based on the shear force (kgf) acceptable to composite resin restorations.

The results showed no significant difference in shear strength between composite resin with $37 \%$ phosphoric acid etching and composite resin with lemon extract etching. Lemon extract contains weak acids namely, citric acid. Citric acid in lemon extract plays a role in the process of dissolution of tooth enamel, because at acidic $\mathrm{pH}$ causes an increase in hydrogen ions, which will damage hydroxyapatite. Lemon extract shows a $\mathrm{pH}$ of 2.5. The degree of acidity affects the coefficient of the reaction rate, that the lower the $\mathrm{pH}$ or the more acidic, the higher the rate of reaction to release Ca-P ions in tooth enamel. High concentrations of $\mathrm{H}+$ ions can dissolve Ca-P bonds in hydroxyapatite so that enamel loses the inorganic minerals that make up hydroxyapatite. This condition is known as the demineralization process.

Demineralization of tooth enamel occurs through a diffusion process which is the process of transferring molecules from the enamel to saliva due to acid. Demineralization occurs when hydroxyapatite (Ca10 (PO4) $6(\mathrm{OH}) 2$ ) crystals in tooth enamel dissolve in acidic conditions into $\mathrm{Ca} 2+$, (PO4) 3- and $\mathrm{OH}-$. This reaction can be explained as follows: Ca10 (PO4) 6 $(\mathrm{OH}) 2+8 \mathrm{H}+\leftrightarrow 10 \mathrm{Ca} 2++6$ (HPO4) $2-+2 \mathrm{H} 2 \mathrm{O}$. The $\mathrm{CaHPO} 4$ molecule is a neutral molecule that will diffuse out of the enamel thus the email will lose the inorganic minerals that make up hydroxyapatite, while the two $\mathrm{OH}$ ions bind to the $\mathrm{H}+$ ion to form $2 \mathrm{H} 2 \mathrm{O}$ in the email ${ }^{18}$.

Demineralization that occurs in a long time will cause the loss of hydroxyapatite crystals so that enamel is more porous and increases the microporosity of tooth enamel. The formed microporosity will be activated by the bonding material and composite resin, resulting in a shear strength that is not much different from the yield of $37 \%$ phosphoric acid.

The results of the SEM (Scanning Electron Microscope) test after the application of lemon extract on bovine teeth also showed the formation of microporosity. 


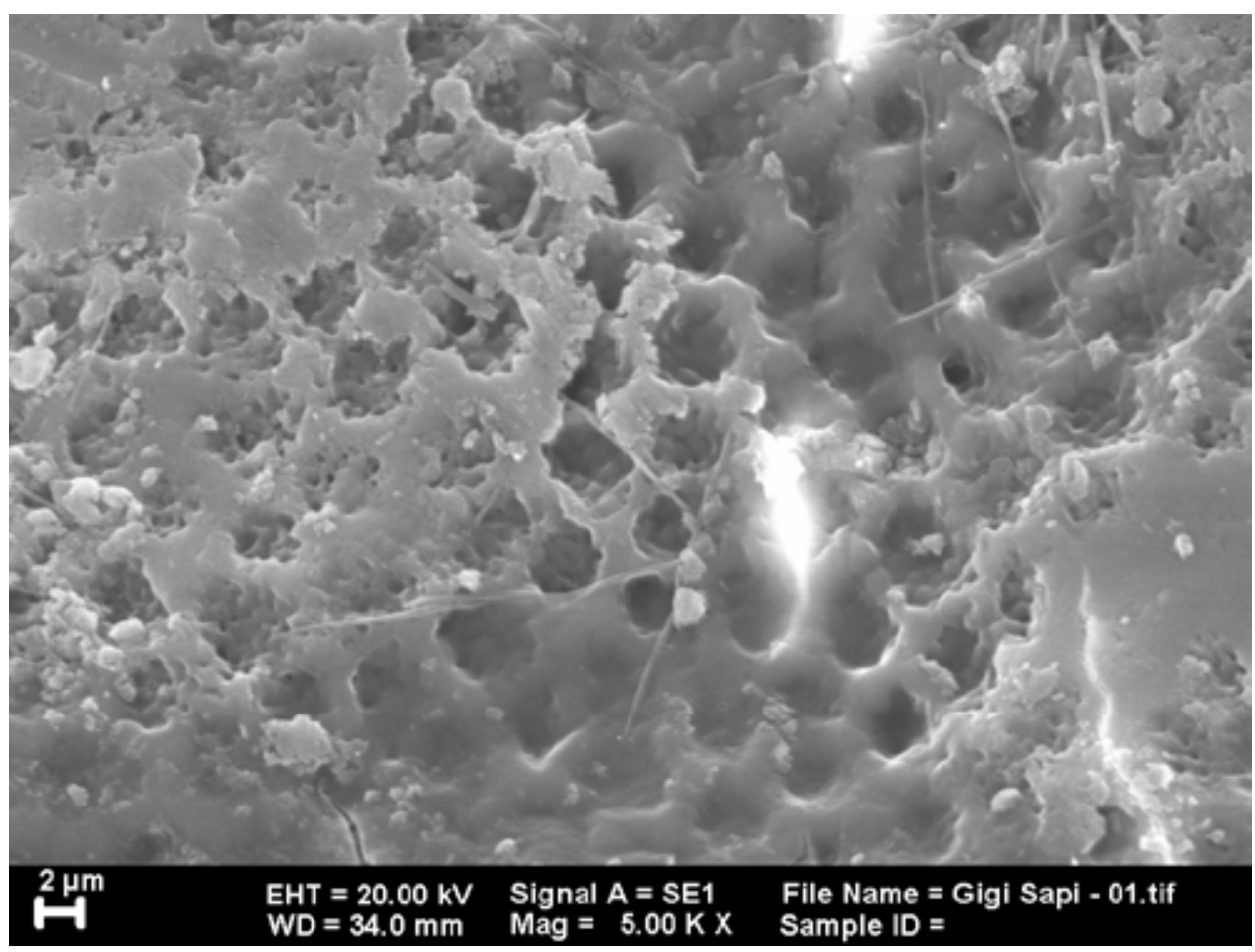

Figure 1: Depth of microporosity of tooth enamel after application of lemon extract for 20 seconds.

Lemon extract is more beneficial in terms of tissue health, because the $\mathrm{pH}$ is not too low when compared to the $\mathrm{pH}$ of $37 \%$ phosphoric acid. Lemon extract also has the ability to remove the smear layer and form microporosity like $37 \%$ phosphoric acid etching. The results showed no significant difference, but taking into account the advantages of lemon extract, the lemon extract can still be used as an alternative to $37 \%$ phosphoric acid etching.

\section{Conclusions}

The conclusion of the research is that lemon extract can be used as an alternative etching material on composite resin spills with shear strength.

\section{Conflict of Interest: None}

\section{Source of Funding: Self-Funding}

Ethical Clearance: This research has obtained research ethics that have been approved by the research team with number 208/HRECCFODM/VIII/2018.

\section{References}

1. Arhun N, Celik C, Yamanel K. Clinical evaluation of resin-based composites in posterior restorations:
Two-year results. Oper Dent. 2010 Jul;35(4):397404.

2. Dennis D, Maitari F, Abidin T, Farahanny W. Evaluation of grape seed extract (Vitis vinifera) as a crosslinker on the stability of dentine collagen in total-etch adhesive systems: An in-vitro study. Int J Res Pharm Sci [Internet]. 2019;10(4):2811-5.

3. Soratur SH. Essentials of dental materials. New Delhi: Jaypee Bros. Medical Publishers; 2002. 341 p.

4. Eliades G, Watts D, Eliades T. Dental hard tissues and bonding: Interfacial phenomena and related properties. Dental Hard Tissues and Bonding: Interfacial Phenomena and Related Properties. Berlin: Springer Berlin Heidelberg; 2005. 1-198 p.

5. Sintawati J, Soemartono SH, Suharsini $M$. Pengaruh Durasi Aplikasi Asam Fosfat 37\% terhadap Kekuatan Geser Restorasi Resin Komposit pada Email Gigi Tetap. J Dent Indones. 2008 Aug 31;15(2):97-103.

6. Malhotra S, Dhawan P, Arora S. A Complete Refresher Science for Class X. New Delhi: Tata McGrawHill; 2007. 27 p.

7. Ghom S, Ghom A. Text Book of Oral Medicine. 
New Delhi: Jaypee Brother Medical Publisher; 2014. 481 p.

8. Tanumiharja M, Burrow MF, Tyas MJ. Microtensile bond strengths of seven dentin adhesive systems. Dent Mater [Internet]. 2000;16(3):180-7.

9. Bako RM, Djafar Z, Renreng I, Wullur CW, Hariyanto. Analysis ofmechanical strength of woven strip composite at petung bamboo (Dendrocalamus asper) epoxy resin tape: Tensile strength properties of bamboo strips. In: 1st International Conference of Interdisciplinary Research on Green Environmental Approach for Sustainable Development, ICROEST 2019 [Internet]. Mechanical Engineering, Faculty of Engineering, Universitas Musamus, Merauke, Indonesia: Institute of Physics Publishing; 2019.

10. Torabinejad M, Walton R. Endodontics Principles and Practice. USA: Elsevier; 2009. 26 p.

11. Fatimatuzzahro N, Haniastuti $\mathrm{T}$, Handajani $\mathrm{J}$. Respon inflamasi pulpa gigi tikus Sprague Dawley setelah aplikasi bahan etsa ethylene diamine tetraacetic acid 19\% dan asam fosfat 37\%. Dent J (Majalah Kedokt Gigi). 2013;46(4):190.

12. Lestari S, Arifin Z, W E. Potensi Air Perasan Belimbing Wuluh (Averrhoa Bilimbi L) Sebagai Bahan Alternatif Dentin Conditioner Dalam Perawatan Konservasi Gigi (In-Vitro). Stomatognatic (J K G Unej). 2011;8(2):90-5.

13. Nugroho DA, Widjijono W, Nuryono N, Asmara
W, Aastuti WD, Ardianata D. Effects of filler volume of nanosisal in compressive strength of composite resin. Dent J (Majalah Kedokt Gigi). 2017;50(4):183.

14. Harahap K, Yudhit A, Sari F. Effect of bench time polymerization on depth of cure of dental composite resin. In: R. Y, editor. International Conference and Exhibition on Innovation in Polymer Science and Technology 2016, IPST 2016 [Internet]. Faculty Dentistry, Universitas Sumatera Utara, Medan, Indonesia: Institute of Physics Publishing; 2017.

15. Farahanny W, Dennis D, Sihombing D. Fracture resistance of various bulk-fill composite resins in class II MOD cavity on premolars: An In Vitro study. World J Dent. 2019;10(3):166-9.

16. Nugraheni $T$, Nuryono $N$, Sunarintyas $S$, Mulyawati E. Composite resin shear bond strength on bleached dentin increased by 35\% sodium ascorbate application. Dent J (Majalah Kedokt Gigi). 2017;50(4):178.

17. Yassen GH, Platt JA, Hara AT. Bovine teeth as substitute for human teeth in dental research: a review of literature. Vol. 53, Journal of oral science. 2011. p. 273-82.

18. Sakaguchi, RL \& Powers J. Craig's : Restorative Dental Materials. 13th Edn. United States.: Elsevier; 2012. 9, 86, 162 p. 